\title{
Legislative Weaknesses for the Foundation and the Function of the Public Enterprises and Trade Companies in Economy Development in Kosova
}

\author{
Dr.sc. Armand Krasniqi, prof. asoc \\ Faculty of Economy, University "Hasan Prishtina" in Prishtina \\ Faculty of Law, University "Haxhi Zeka" in Peja
}

Doi:10.5901/mjss.2013.v4n11p738

\begin{abstract}
Kosovo is going through a difficult phase of social transition and problematic history. The reasons for this situation are of different nature. Until now the competent institutions, despite their commitments, do not have noticeable encouraging results with a view toward the economic growth and enhancing the employability of youth as the European Union norms require. Among the issues that require solutions and was not given priority, is the scarce and copied legislation that regulates the establishment of public companies, competences that are under the responsibility of state authorities. On the other side, the primary and secondary legislation dedicated to commercial - private enterprises establishment is more appropriated while to the partnership companies and limited partnership is not recognized the quality as a legal entity. Although the government is trying to compile and submit a compatible legislation, according to European Union standard, the establishment of a public company is still limited. The institutions with this legislation have the possibility to create only Joint Stock Companies. If we handle this issue in comparative plan we can conclude that the legislation for public companies is weak while for trade companies are unclear. For this reason not only is necessary but is emergent that state authorities, even in central and local level, engage experts that based to the economic development level, to provide appropriate legislation in way to give the possibility to the state authorities to establish other enterprises and to reconsider the possibilities to provide legal subjectivity to trade companies.
\end{abstract}

Key words: trade companies, Joint Stock Companies, legislation, institutions.

\section{Introduction}

The aim of this paper is focused on the identification of some serious weaknesses of primary legislation of the Republic of Kosovo for the foundation and the successful function of, primary, Public Enterprises and partially of private enterprises. To identify and to give a critical think for these weaknesses is necessary to discuss respectively to pose the problem in historical plan.The motivation to deal with this problem derives from the fact that the most of the juridical and economical literature is focused only in the aspect of economical efficiency of the enterprises and to not treat the juridical issues. For this reason, based in this aim must be underlined that the social-economical development in the republic of Kosova, looking at the historical plan, is very complex. First, because in 1945-1989 the country was an autonomous province of ex Yugoslavia and the most poor one. In 1989 after the dissolution of the former Yugoslavia, the Republic of Serbia with violent instruments suspended the constitutional autonomy of Kosova and until 1999 have destroyed every economical valuable segments in the former Yugoslavia. ${ }^{1}$ During the period of after war with the Resolution 1244 (1999) of the Security Council of United Nations of 10 June, has acted through the United Nation Mission in Kosovo (UNMIK) taking the responsibility to administrate Kosova. The special Representative of the General Secretary until the independence of Kosova in 2007 was the highest authority in Kosova. The authorizations of this mission were very important and included all the legislative and executive decisions and also the administration of law and the economy. UNMIK had created juridical bases for the foundation and formation of the enterprises and in this case a considerable number of Public Enterprises have been partially revitalized but in unfavorable circumstances, with very low level of capacities use and potential activation. After the declaration of independence the legal and real authority has been transferred to the new institutions of Kosova.

\footnotetext{
1 In a research report of "Riinvest" institute 2012 and based in a survey developed in the enterprises regarding the loses during the war of 1999 are $21.2 \%$ of the physic capital. Only ten of 192 have been damaged by the war. Almost half of them (44\%) had $1-10$ million Dem, and $15 \%$ of them until 100 million DEM. The biggest damage had the agro industry, metal industry, agriculture, transport, etc. Almost every enterprise had loses of 5,2 million DEM.
} 
Because of the irreplaceable importance these enterprises and the commercial societies have in the economy development and for the citizens, as in all the world, the legislations in Kosova and the way of the foundation, function and managing of these enterprises is regulated based in the Law for Public Enterprises (LPE) and the Law for Commercial Societies (LCS). ${ }^{2}$

The present paper aims to encourage the professional and scientific debate for this problem. The idea is that the issues presented in the future must be treated in multidimensional aspects because the juridical and economical nature of the enterprises is multidimensional.

\section{Types of business enterprises according to the actual legislation in Kosova}

The different organizational and functional formations, in the quality of juridical - business persons are founded and structured with different modalities, represented, acting and function in different time and places, with different denomination and terms. Considering that in reality these are all synonyms and consequently in other forms and denominations these are used in wrong way. The most widespread forms of the organizations are: for business organizations - business organization, commercial organization) for companies - (company), enterprise (enterprise, establishment, Unternehmen), corporation (Corporation), society (society, societe), firm (firm, commercial firm, business firm), partnership, (partnership, societe) etc.

It should be stressed that the business activities of different business subjects in Kosova after the last war, for the first time are systemized with the law for public enterprises and for the commercial societies, as fundamental law of organization and function of different business activities in Kosova.

We consider that in Albanian language the Law for public enterprises in terms of denomination is complete but the Law for commercial society not only is incomplete but also inadequate. This finding confirms the fact that the law for commercial societies in English language (as original language for drafting the law) is denominated in a right way in our language as Law on Business Organizations. Since the denomination of this important law in Albanian language is inadequate and antipode with the trends, dynamics and the level of business activities development and further, and the needs and developing trend always increasing, for pragmatic scopes, practical and unified in this text for the commercial societies further on will be used the phrase - business organizations.

The phrase business organizations of Kosova is a general denomination, that according to law means and includes every modality and form of the business founded in Kosova according to the law in treatment as: personal business enterprise, a general partnership, limited; a limited hability Company; or joint stock company; (art. 4 of the Law for Business Organizations in Kosova.

These types or forms of business organizations, can be founded, act and operate in Kosova only if they develop legal activities. These organizations according to the law can be founded and registered by every physical person, society or group composed by two or more persons and/or many other business modalities (art. 5 of the Law). The business activity according to the law means every type of regular activity or repeated that includes: goods and/or services, propriety or/and works for every person or organization in exchange of any method of payment or compensation; with the condition that the employee which works for the employer is not considered that is executing "business activity" and his services will be compensated according to the contract between the employer and the employee.

\section{Juridical basis for the foundation of the public enterprises in Kosova}

There are many economical activities in Kosova in the last years as result of social development after the war as we mentioned above. This sustainable level of the activities, in the general level aspect, has overpasses the capacity and the ability to support the private enterprises and regulative systems of the public sector, to act with quality and efficiency. The public enterprises are established according the Law on Public Enterprises nr. L.03/087 dated 18.06.2008. Analyzing this law we observe that its structure is interesting for the fact that is related to the rights and the duties of these enterprises that are based on the Law on Commercial Societies ${ }^{3}$. This is a law act that regulates the establishment and the function of private enterprises in our country. The principal characteristics of this law are: all the public enterprises are propriety of the Republic of Kosova. The enterprises are divided in central and local. According to the criterions for the

\footnotetext{
2 The law on Public Enterprises nr. L - 03 / 087 and the law on Trade Societies nr. L - 02 / 123

3 The law on public enterprises, art. 2.1.
} 
establishment of local public enterprises and the participation of the municipalities in directors boards of regional enterprises of water, with the aim to govern the corporation of the public enterprises acting in municipalities are regulated with special regulative. ${ }^{4}$

All the public enterprises, local, regional or central are joint stock companies and consequently the local governments respectively the central government has exclusive competences in executing the rights of the shareholders. The supervision of these enterprises is realized through the Board of the Directors and Auditing Commissions. The government responds to the Parliament for the supervision method according to which the government, the Ministry and the Unit for the Policies and Monitoring the PE execute their competences and responsibilities given by law. The government reports to the Parliament in annual bases on the performance of these authorizations and responsibilities and on the achievement of the objectives determined in the art. 6.1 of this law. The government provides quantitative and sustainable dates for the public and for the Parliament. The stocks of a public enterprise can be sold if such decision is approved in writing and the Governmental Commission is authorized for the privatization but this decision must be approved by the majority of the parliament. After the approval of this decision by the government and the Parliament, the Governmental Commission for Privatization is authorized to realize a tender and sell the stocks. Have to be emphasized that if an enterprise had less than $50 \%$ of its propriety this enterprise is not considered a Public Enterprise. In this cases automatically is acted on the base of the Law on Commercial Societies and other laws applicable in the Republic of Kosova.

\section{What is a Public Enterprise}

The constitution of the Republic of Kosova defines that "the Republic of Kosova is owner of all the enterprises in the Republic of Kosova, that are known as Public Enterprises....all the obligations of these enterprises are obligations of the Republic of Kosova....The propriety rights in a Public Enterprise that provides services for a municipality or a limited number of municipalities will be part of that/those municipalities .......as well as the relevant obligations" The Public Enterprises in Kosova are divided in Central Public Enterprises (CPE), the Government can privatize, to grand concession or rent, and the Local Public Enterprises (LPE) and the owners are the municipalities, determined by the law 04/L-111 and the law nr. 03/1-087 for the public enterprises. The Government and the municipalities administrate the PE in their propriety only through methods foreseen by law and they have no right to get involved in managing and in the propriety of a PE. On the other side the Law for Local Auto government is a fundamental and a general law that regulates and decides the auto government normative system as a guaranteed right with Constitution. According to this law the municipalities have the full and exclusive right to offer and manage these public services for the local interests. This give the possibility to choose the way of offering the public services that might be through a department of the municipality, through a contracted private company or through a public enterprise. Because of a non harmonization of this law with the laws that regulate the managing of PE has been created a confusion regarding the competences of the municipalities over some PE and as consequence some Mayors have requested to have control in managing of these public enterprises or to have the right to found municipality public enterprises.

\section{The situation of Public Enterprises in negative context}

We consider that the options offered by actual Law for the Public Law in the Republic of Kosova are poor and negative in two aspects:

a) First, the law in question does not offer the possibility and further information for the enterprises except the Joint stock companies. If we analyze in the comparative context the formation of public enterprises founded by certain states then we conclude that our country gives the possibility to central and local institutions to found only Join Stock Companies. Is interesting that in some countries in south-east Europe the law for public enterprises does not prohibit the other formations and the institutions have the right to make the necessary alternative solutions.

b) Second: based in the actual situation of our country, offering only a formation - Joint Stock Company, is not only unreasonable but also contradictory and clearly testify the political influence in the activities of the public enterprises not for the public interest but for the interest of certain

${ }^{4}$ The rule $\mathrm{nr}$. 02/2012on the criterions for the foundation of the local public enterprises and the participation of the municipalities in Directors Boards in Water Regional Enterprise. 
groups and individuals with influence in the society. The best and more advanced practices several times have testify that except every form or modality of organization and activities of the public enterprises the influence of the government and its exponents is considerable ${ }^{5}$ the influence of government on these enterprises can be reflected: directly - through relevant decisions for these enterprises related to the prices, development policies etc; indirectly «ex - ante »- through the selection of monitoring and inspection bodies; indirectly « ex - post » - through the verification of finances, as arbiters in the relations with the third persons, for example with the consumers ${ }^{6}$. Is to be mentioned that the government has "played" and "experimented" with the status of these enterprises. In some countries has been realized the privatization process, in some others has just started, in other countries this process is ongoing; this process is continuing also in countries called "in transition" part of which is Kosova.

\section{What are the duties that can be taken into consideration by the institutions}

Even there is achieved a progress, there have to be done improvements of legal infrastructure in Kosova in way to offer a favorable environment and possibilities that can be used by the public institutions and investors.

Some of the key factors on which have to be addressed and urgently act for their improvement are:

$\rightarrow$ Change and improvement of the Law on Public Enterprises and creating possibilities for state institutions of all levels to have in their disposition the possibility to found some formations - business enterprises;

$\leftarrow$ Change and improvement of laws system in economy field, regarding the company in general, and especially to change the capital ownership and the following laws:

Completing the law for Securities, Foreign Investments, Foreign Trade, and others laws of the Republic of Kosova (the Law on Privatization of the Privatization of Action Plan Found Agency, the Law for Public Enterprises, Law on Concessions, etc), creating conditions for further development of enterprises and the transformation of the public ownership in other forms.

$\rightarrow$ The legal and regulative environment: the legal environment of Kosova is deficient of a court system still in consolidation and inefficient that does not offer necessary protection for the investors. Some important laws are missing or must be changed. Even the independent regulators are founded during UNMIK administration, after June 2008 have been noted tendencies of some ministries to get involved in the regulators mandate. Some regulatory had find difficulties because of some vacuums caused by the delay in selecting the board members by the Parliament. The vacant places are opened for period of time avoiding seriously, in this way, the function of relevant institutions. There is no political support for the work of the independent institutions and this influence negatively. The lack of adequate protection of the consumer has negative impact in the trade liberalization and economical development in general.

\section{OECD guideline implementation on Public Enterprise in Kosova}

One of the most relevant issues is to evaluate if the OECD Guidelines are implemented in the Public Enterprises in Kosova, if yes, in which measure. The Ministry of Economy urgently must prepare a Corporative Governmental Code for the PE that is according the Guidelines of the EOCD. Until now even the ministry neither the Public Enterprises has reported for the respect of this code.

According to the legal and regulative issues the actual system of the Public Enterprises is composed by the following framework: the ministries of the Government of Kosova, Public Enterprises and Regulators. According to the information actually have confirmed that the regulators, by law, must be independent but in reality they cannot be completely independent because of the finances and government intervention. In this aspect, the law foresees individual entrances of the regulators by the registration taxes. The regulators in the actual circumstances depend by Kosova Budget Financing and their independence is very limited. Another issue is that the regulators do not collaborate enough with the governmental institutions and enterprises and this limits their efficiency. To overpass this situation must exist a type of activities coordination between the respective ministries and regulators.

\footnotetext{
5 The editorial "Bordet si mundësi e militantëve politik" www. http://gazetajnk.com/?cid=1,3,796

${ }^{6}$ For example the Government of the USA through its Trade Federal Commission realize a special control over the business in general.
} 


\section{Conclusions}

During the last 15 years, our country as all the transition economies, have tried to adopt the legislation and the codes of corporative governmental similar with those of the Continental Europe. But, the legal institutions and the financial trades in undeveloped or in developing countries have obstacle this process especially in south-east Europe. There is a massive progress on paper; anyway there is a vacuum between the laws on paper and those in practice. The influence of the new laws and the regulative is far away from the regular situation and this composes a defect in the foreign finances to recommend investments or new capital for the enterprise.

The governmental framework of the Public Enterprises is referred to a group of rules according to which the enterprises are managed in the interest of their owners, investors and other interested parties; mechanisms according to which the owners monitor the work of the management. The ineffectiveness to execute an efficient framework of corporative government, for example, if there is no possibility to found certain enterprises by the institutions and if there is no efficient control then there will be a poor performance of the Public Enterprises, causing serious consequences for the efficiency and the competitive ability of the economy in Kosova. A better legal framework offers security for the owners, potential investors and lenders because the interests of the enterprise are protected and support the approach of the company in external resources. The lack of such formations automatically produce negative effects for a good governance and do not encourage the investors, especially the foreign investors and in this way slows the further evolution of the ownership and contributes in economy stagnation.

The present paper do not disputes the fact that the enterprise is an important factor to the society and the country that reflects the economy development level and social stability in general. By following the example of the developed countries we can support the development of the society in our in transition country and as consequence the economy in general. To develop the economy we must follow the IOM directives for the small and medium enterprises. Principally to stimulate the youth and ambitious people with the ability to do this progress.

The Public Enterprises are created and partially operate in accordance with the law that regulates their juridical position. The State capital in a Public Enterprise is divided in stocks or specific stocks according to the value and the incomes of the company. The State capital and the funds of the public enterprises are invested by the government as well as the use of the propriety and the other right of the State.

The role of the public enterprises is essential for the society and the activities of these enterprises are predefined by law in the fields as follow:

production, distribution of the energy, production and processing of the cobbles, research, distribution and transport of the fuel and natural and liquid gas, selling of the fuel and its products, post and air transportation, telecommunication, media services, the use and management of the public goods (water, roads, mineral resources, forests, rivers, lakes, banks, etc) and services.

The public companies are created to support the municipality services, to manage the goods with general interest.

The adoption of a modern legislative framework in accordance with the OECD Guidelines for corporative governance of State Enterprises is one of the fundamental issues that will face the Govern of Kosova (and reformative governments in all transition economies). With a poor ownership rights system and the rule of law in general an effective framework for corporative governance is essential for the public enterprises and to attract investments (especially foreign investments) that are necessary and indispensable for our economy stabilization.

Kosova is in an important phase of its democratic transition and toward a trade economy. Kosova's final status also after the declaration of its independence is contested by some EU States even the positive attitude of the international community the problems raised with the integration process are not undersized. For this reason is important that the Government of Kosova create its policies for the Public Enterprises (and also for other important fields) as soon as possible. Continuing with the actual situation of the Public Enterprises will create poor performance, increase of subventions and increasing level of corruption. The present situation can change by applying adequate measures for the improvement of the legislation as abovementioned in this paper, especially by implementing the Guidelines of OECD. This will contribute and improve also other sectors of the economy and the reducing the pressures for more taxes and improving the other govern services. On the other side will support the privatization of the companies as one of the aims of the Government of Kosova. 


\section{Literature}

Baker, G., M. Jensen and K. Murphy (1988), Compensation and Incentives: Practice vs. Theory, Journal of Finance, 43: 593-616.

Barca, F. and M. Brecht (2001), The Control of Corporate Europe, Oxford: Oxford University Press.

Bebchuk, L.A., J.M. Fried and D.I. Walker (2002), Managerial Power and Rent Extraction in the Design of Executive Compensation, The University of Chicago Law Review, 69:751-846.

Ndërmarrjet shoqërore dhe transformimi /privatizimi i tyre - Draft i Raportit Hulumtues Raport i përgatitur në bashkëpunim me Qendrën Ndërkombëtare për Ndërmarrjet Private (CIPE) dhe e mbështetur nga Agjencia e SHBA-ve për Zhvillim Ndërkombëtarë (USAID) Prishtinë, 8 Mars, 2001

OECD (1999), Principles of Corporate Governance, Paris: OECD.

OECD (2002), Comparative Study of Corporate Governance Codes Relevant to the European Union and its Member States, Paris: OECD (January).

OECD (2003), White Paper on Corporate Governance in South East Europe, Paris: OECD (July)

OECD (2005), Guidelines on the Corporate Governance of State-Owned Enterprises, Paris: OECD (April).

Ligji mbi ndërmarrjet publike nr. L - 03 / 087

Ligji për shoqëritë Tregtare nr. L - 02 / 123

Rregullorja nr. 02/2012 mbi kriteret për krijimin e ndërmarrjeve publike lokale dhe pjesëmarrja e komunave në bordet e drejtorëve të ndërmarrjeve rajonale të ujit 